\title{
The Cloud University Strategy
}

\section{Felipe Fernandez' ; Maurício Andrade De Lima² ; José Baltazar Salgueirinho Osório D’Andrade Guerra³; Valdemiro Da Rocha Júnior ${ }^{4}$}

\begin{abstract}
1 Bachelor in International Relations, Universidade do Sul de Santa Catarina (UNISUL), 2012; Master student in Administration, research area: Strategic Administration at UNISUL (Class I- 2013); Student researcher in the Research Interdisciplinary Group in Administration, Tourism and International Relations (GIPART-UNISUL) since 2009. Participated successfully as an exchange student in the Master in Entrepreneurship and Internationalization Program (2010-2011) from the Higher Studies Institute of Accountancy and Administration of Porto, Portugal (ISCAP).

2 José Baltazar Salgueirinho Osório de Andrade Guerra, PhD, Dean and Professor at Unisul Business School (Universidade do Sul de Santa Catarina - UNISUL, Brazil). Director, at UNISUL of two research projects: JELARE - Joint European-Latin American Universities Renewable Energies Project; and REGSA - Promoting Renewable Electricity Generation in South America. Both projects financed by the European Union (through ALFA III and the thematic program for environment and sustainable management of natural resources, including energy). Member of The Scientific Committees of the World Symposium on Sustainable Development at Universities (WSSD-U-2012), a parallel event of Rio+20, and the Green Campus Summit 2013. Organizer and author and of several books in: Economics, International Relations, Environment, Sustainability and Renewable Energy.

${ }^{3}$ Bachelor in Economic Science - Universidade Federal de Santa Catarina - UFSC (1992), PhD in Production Engineering, UFSC (2003), Master in Production Engineering, UFSC (1999) and Specialist in University Management and Leadership, Universidade do Sul de Santa Catarina - UNISUL / University of Sherbrook / IGLU / OUI / Canada (2004). Since 2000 working at UNISUL in the administrative and academic areas. Since 2011 exclusively dedicated to the academic area as undergraduation and graduation professor (Lato Sensu and Stricto Sensu) and as vice-coordinator of the Post-Graduation Program in Administration (PPGA). From 2001 to 2003 integrated the Strategic Planning Advisory (ASPLAN); from 2004 to 2007 worked as director of the North of the Island Unit; from 2007 to 2008 as Economic-Financial Analyst of the Director of the Campus of the Metropolitan Florianopolis; from 2008 to 2009 as Controller; from 2009 to 2011 as Economic-Financial Institutional Advisory (to the Dean). Interests: University Management, Evaluation of the Organizational Performance, Strategic Management.

${ }^{4}$ Bachelor in International Relations, Universidade do Sul de Santa Catarina (UNISUL), 2012 Bachelor in Pharmacy and Biochemistry, Universidade Federal de Santa Catarina (UFSC) in 2008; Master in Administration, research area: Strategic Administration, UNISUL (Class I- 2013); Bachelor in Social Sciences, UFSC, 2013.
\end{abstract}

oScholedge International Journal of Multidisciplinary \& Allied Studies (ISSN 2394-336X), Vol.02, Issue 11 (2015) p8-28. Published by: Scholedge R\&D Center [www.theSCHOLEDGE.org] [Email: sijmas@scholedge.org]

\section{ABSTRACT}

This theoretical essay aims at raising possibilities for the improvement of the performance of universities. It is a qualitative, exploratory and hypothetical-deductive study, based on a review-ofliterature technique. The results point to the development of "Cloud University" as a tool for improving the performance of universities.

Keywords: Performance Evaluation of Higher Education, University, Education

\section{RESUMO}

Esse artigo é um ensaio teórico que visa levantar possibilidades estratégicas para a melhoria do desempenho das universidades. Trata-se de um estudo qualitativo, exploratório e hipotéticodedutivo, com técnica de análise bibliográfica. Os resultados apontam para o desenvolvimento da “Nuvem Universitária" enquanto ferramenta estratégica de melhoria do desempenho das Universidades.

Palavras-Chave: Avaliação do Desempenho do Ensino Superior; Universidade; Educação. 


\section{INTRODUCTION - ONE UNIVERSITY, TWO CONCEPTS}

There has been a very strong academic debate recently around the concept of university (Dias Sobrinho, 2004). Whereas one trend comprises the university under an organizational logic and seeks for administrative responses from such assumption (Rizzatti; Dobes, 2004; Andrade, 2002; Baldridge, 1982; Cohen e March, 1974; Millet, 1962; Weick, 1976; Meyer Jr., 2005), the other trend analyzes university from the standpoint of a social institution/public commodity (Chauí, 2003; Dias Sobrinho, 2004; Sguissardi, 2005).

Considering the assumptions above, both groups give totally different responses for what seems to be "bad" and "good" when strategies of higher education management are concerned. The group who sees university from the private/mercantile/public service standpoint understands education as a commodity, since its social return would be by aggregating value to the subject and, therefore, it would be costly. This is the philosophy of the World Bank and its project for education. (World Bank, 1986; 1994; World Bank/Johnstone, 1998). According to this philosophy, the individuals would have the right to know exactly where they were investing. For that, the Government should regulate the market, constantly providing rates to attest the quality of the services offered, and to present rankings that are capable of making the most qualified individuals reach the best institutions for their formation (Harvard effect) (Dias Sobrinho, 2004, 2008 (a), 2008 (b); Sguissardi, 2005, 2008; Chauí, 2003). Such concept is perfectly aligned to the values of capitalism.

On the other hand, university seen as a public commodity understands education as a fundamental right and duty of the State. From this point of view, education would consist on the construction of meanings and in the formation of human beings capable of promoting the material and intellectual improvement of the society. Those values diverge thoroughly from the capitalism (Dias Sobrinho, 2004, 2008 (a), 2008 (b); Sguissardi, 2005, 2008; Chauí, 2003). That is the reason why the concept of university is so disputed; it is, above all, a dispute about the concept of world and society. While one type of university is pseudo-meritocratic, elitist and excluding, the other considers itself democratic, inclusive and not classist.

In this article the authors understand that both concepts can establish a dialogue with the newmillennium university, resulting in a complex social organization, aimed at attending the market 
demand, without abdicating from the social ends. The question is: "Which strategy can guarantee a good performance from universities, combining social economic responsibilities?"

Taking the above into consideration, we divided this study into five sections: introduction; methodology; a general view of the organizational management strategies; the presentation of metaphors of "cloud university" compared with the "university within a matchbox" as a management model used today for most of those organizations, along with the elaboration of the assumption of "university cloud" as a model for the improvement of the management of these institutions; and the conclusion. We use the "cloud" metaphor to suggest answers to the problem on how to adapt the universities (a secular institution) to the new millennium, articulating social and market values, trying to have an education that responds simultaneously to the laws of efficiency and efficacy inherent to the market and able to preserve some autonomy to give social contribution, which are basic requirements of some sectors of the organized civil society. To conclude, we present our considerations about the issue to be studied and the references used in the elaboration of the article.

\subsection{METHODOLOGY}

This is a theoretical review, classified as qualitative and exploratory (metaphoric), based on a hypothetical-deductive approach. In relation to the qualitative characterization, we present the difference as defined by Appolinário (2009), for whom the concept of variable is usually not adopted in a qualitative research, and the data analysis is, typically, subjective, with low or null possibility of generalization. This approach is more commonly used in the Social Sciences. This definition comes to complement Triviños' assertions. For him, the qualitative research has the natural environment as direct data source and the researcher is a key-instrument; the research is descriptive and the researchers are concerned with the process, not just with the products and results, tending to use the induction in their data analysis.

We accept Selltiz's interpretation of the exploratory view, as in Marconi-Lakatus (1999): “the definition applied to the innovative, systematic or exploratory studies that emphasize the breakthrough of ideas and understandings". The metaphoric argumentation is justified because it is a theoretical essay. The use of that argumentation is based on the propositions of Morgan (1980), who affirms that in Social Sciences the schools of the thought, in Social Sciences, "are based on the use of different kinds of metaphor as bases for the investigation". In our case, we work with two metaphors: the "Cloud" and the "Matchbox". 
The approach to the research will be the scientific deductive-hypothetical methodology, initially elaborated by Karl Popper. According to Heerdt e Leonel (2007), Karl Popper "believed that the scientific progress happened in three stages: to establish the problem; to settle the assumptions or provisory solutions; and the tentative refutation of such conjectures."

Aligned with such concepts, Reali; Antiseri (1991, p.1025-1026) state that the research begins with a problem, and, therefore, it will consist exactly on seeking its solution. Creativity will be necessary for "good and new ideas" to generate and build hypotheses and conjectures to solve a particular problem. In this sense, this study establishes as a problem the search for a strategy that can contribute for the good performance of the universities, conjoining social responsibility and economic imperatives.

Reali; Antiseri (1991, p.1025-1026) also affirm that when a hypothesis is established, it must be confirmed or not and the consequences must be verified. So, when a hypothesis is established, we must prove it. If all consequences actually occur, the assumption is confirmed; if at least one of them does not occur, then the initial assumption is considered false. Therefore, this study is limited to the proposition of a new assumption to solve the problem presented above. This same assumption, combined with the paradigms accepted between the authors in a prior agreement, during the elaboration of the study, will in the future be a case for investigation and empirical and theoretical evaluation by the academy. We call such assumption the "management model of the university cloud".

We have adopted the documental and bibliographic analysis for the research theoretical fundamentals for the elaboration of the hypothesis. The articles and documents studies for this investigation was the bibliography used in the teaching plan of the subject matter Evaluation of the Performance in the Higher Education, of the Post-Graduation Program in Administration - PPGA UNISUL as a basis for the crossing of the references and establishment of a final sample of documents and articles to be analyzed. The result was that 22 articles on the issue have been read, as well as three documents from the World Bank. From such basis the researchers constructed an assumption of a "cloud university" management strategy. Although not quantified, other articles studied in several disciplines of the PPGA have also been used to support the hypothesis construction. 
This section will discuss the key concept in the research concerning the comprehension of the theoretical construct of strategy. We will first introduce a heraldic contextualization of strategy, and then how it was inserted in the world of the organizational management and administration. We conclude by selecting the concept that, according to the authors, is more adequate for the theoretical model for the university management here discussed.

Etymologically, the word strategy means literally the general's art, and derives from the Greek expression estrategos (who were the higher commanders in charge of creating and planning the war actions in the Ancient Greece). We observe that, in the ancient times, the strategy aimed at the creation of the best actions and troop movements that would lead the soldiers to the victory.

Strategy as a military terminology changed meaning during Napoleon Bonaparte's times. Bonaparte emphasized strategies exclusively aiming at victory. By definition, ancient strategy took into consideration the defeat and its consequences. So, strategists prior to Bonaparte, when planning wars, also thought about the possibility of being overpowered and the ways to minimize the results that could be potentially harmful to the status quo. In other words, after Napoleon, the strategist would be more exposed to risk (AMARAL, 2005).

In accordance to the perspectives mentioned before, Ferreira (2006, p. 380) presents the following concepts for strategy: "1. Military art of planning and executing the movement and operations of troops, ships and/or airplanes to reach or maintain relative positions and warlike potentials favorable to future tactic actions. 2. The art of applying available means or exploring favorable conditions, aiming at specific goals".

Today, strategy became a key word in the market. The traditional organizations, due to the several changes the market underwent, are required to adjust to the new concepts of management so that they become more efficient and competitive. It is a new reality that comprises the capacity to adapt to new profiles, both of organizations and collaborators and mainly of customers (consumers) who, along the last two decades, became more demanding in relation to the quality and price of the products and services they acquire. In this new context, the term "strategy" gained importance in the organizational world, no matter the size, the management system, or the segment of the organization. It is a question of survival in the growingly competitive market (SANTOS; ALVES; ALMEIDA 2007, p. 60-61). 
A positive point in the pressure of the demands exercised by the business market today is the fact that the richer the environment - the more organizations we have -, the higher the competitiveness, which makes the business organizations evolve constantly, formulating new strategies to endure and become distinguished in the market. Another positive point in the competitiveness is the fact that it offers and motivates the creativity of the business managers, who must be aware of the quick changes to adapt to the new rules, and not fall behind the competitors (HENDERSON, 1998).

This competitive scenario eventually makes an attractive market for the organizations that like challenges and do not fear to use their creativity to develop the best strategies to beat their competitors and maintain their longevity in the market (ANSOFF; MCDONNEL, 1993).

The strategic administration, as we know it today, was constituted in the middle of the 1980s. Although its embryo dates from the 1960s, it is a relatively new field within the administration. However, the field has only been seriously studied as from the 80s (MINTZBERG et al, 2006).

Along the time, the organizations adapted the strategic military planning to the marketing context. Its main characteristic was to surprise the competitor, aiming at the victory. In this way, even the most traditional organizations - for example, the universities -, embedded in the business logic, tried to develop strategies to surprise the competitors and their marketing areas, that is, began to create mechanisms of management and actions to consolidate their wallet of customers, as well as the maintenance of the old clients and the conquest of new ones. Thus, strategy became a fundamental business management tool for the survival of the organizations in the contemporary scenario (AMARAL, 2005).

Translated into the administration context, strategy carries paradigmatic backgrounds that will reflect on the studies in the area. It means that understanding of strategy falls upon so many standpoints that, along the time, they have been distributed among several different schools (MINTZBERG; AHLSTRAND; LAMPEL, 2000).

Strategic Administration, during its conceptualization stage, was influenced by Taylor (1947), Barnard (1938), Simon (1947) and Selznick (1957), and by theories of Economic Organization and Bureaucracy. In the 1960s, an increasing number of authors participated in the construction of this line of research. As an example, we can cite Alfred Chandler, Igor Ansoff and Kenneth Andrews. (FURRER; THOMAS; GOUSSEVSKAIA, 2008). 
Since the 1970s the field began to shape its own characteristics. Strategic Administration as a field of studies split between the approach of the descriptive studies on how the strategies are formed and implemented; and on the organizational development, aimed at the exterior and interested in a structural approach, with a substantial application of case studies as a methodology of analysis and scientific construction (FURRER; THOMAS; GOUSSEVSKAIA, 2008).

For Furrer, Thomas and Goussevskaia (2008) the studies of Strategic Administration in the 1980s suffered influence of the Resource Based View, which fragmented even more the field. The construction process of the strategies turned to the inside of the organizations. In this period the Resource Based View (RBV), to generate competitive advantage, correlated the resources (in all forms) of the organization to its marketing performance. These theories assumed that the maintenance of the competitive advantages would start inside and come to the outside of the organization. The concept goes against Porter's view. Porter associates the development of the strategies with the organizational interactions with the strengths of the market. (ITO; GIMENEZ, 2011).

Penrose (2006) defines the RBV as a form of approach that matches the internal analysis of the happenings within the organizational realm with a series of external phenomena. Thus, by analyzing the sector where the particular organization is inserted and the competitive environment around it, the RBV can offer an interaction between the analysis of the internal and the external point of view of the organization.

Ito e Gimenez (2011) state that the RBV uses, in its original development, the theories of Economics, evolving in the margin of the conventional investigations, which were represented by the mainstream paradigms of the field. Schumpeter, Winter, Nelson and Penrose can be pointed out as the pioneers in these studies.

The core of the researches in RBV would be to identify the intrinsic resources in an organization, and how these resources could generate a sustainable competitive advantage along the time. Thus, to better understand the RBV, we must have very well defined what and which those resources are. Jay Barney (1991) explains that by 'resources of an organization' we understand all the attributes that qualify it, helping to define and implant strategies. So, 'resource' is considered something very broad in meaning, something not restricted to materiality, but personal and intangible as well. 
The RBV is also linked to the understanding of the dynamics' capacities, collaborating with the theoretical improvement that concerns the competences and practices resulting from the organizational strategies. The latter would give the RBV a better capacity to confront the external environment through the mobilization of internal resources. (EISENHARDT; MARTIN, 2000). In this way, the paradigm that comprises the strategy from an endogenous-exogenous point of view can be considered one of the great schools of the business strategy studies.

On another plan, there are authors that understand the strategic construction from the outside to the inside of the organization, such as an exogenous-endogenous paradigm. Therefore, in the procedural approach, according to Michael Porter, the strategy is conceived as a process through which the managers of the organization formulate the best ways to solve its dilemmas, and the more adequate solution so that it can become an outstanding organization in relation to the competition. This strategic process goes through several stages, beginning with the identification of the weak and strong points of the organization. After observing which generates more dilemmas, the best actions will be taken; the best management tools will be chosen; the time to execute the actions will be measured; and which will be the actors involved and the levels of responsibility of each of them (MINTZBERG et al, 2006).

Porter (1999) states that the basis of a business strategy lies on the fact that it can mean a competitive differential for the organization so that the market (customers, consumers or suppliers) realizes the difference. Thus, the business strategies must seek, through planned actions, to generate values that make the organization act in a diverse way, making it more attractive to the customers.

This competitive advantage derived of the elaboration of a differenced strategy is kept until the competitors identify the most outstanding actions developed by the organization. In other words, this is a usually short-term competitive advantage, because the competition quickly creates new strategies and actions, aiming at overpowering the opponent, originating a circle of organizational creation and dispute in the search for new actions that will, in their turn, pull all of them forward (ANSOFF; MCDONNEL, 1993).

After presenting two of the main paradigms of the academic strategy, we can also understand strategy conceptually from several other angles. According to Meirelles (2003, p. 40) "[...] strategy is 
the creation of exclusive and valuable competitive position that involves a different and compatible set of activities; [...] it is to execute excluding options in the competition; it is to choose what to do , but fundamentally what not to do".

To Henderson (1998), another way of understanding the strategy is to plan the best actions for the development and adjustment of the market niche, so that they can bring more competitive advantages when facing the competition.

Yet, Mintzberg e Quinn (2001, p. 186) state that “[...] strategy is one of those words that people define in a way and use in a different way, without actually realizing the difference". Strategy, in the view of these authors, goes through many approaches that are complementary in their differences of perception.

Contemporary, interpretativist and non-determinist views emerge as new paradigms in the area. The interpretativist became a highlight with the work of Pettigrew (1977). In Pettigrew's words, (1977, p.78) a good administrative strategy is the one that is composed by "choices that are made and executed in processes that involve individuals and their groups, in different organizational levels, and that develop to form a pattern of thoughts about the world, of evaluation and attitudes about it".

In this context we believe, in an approximation to Pettigrew's concept (1977), that the development of the theoretical model in cloud, proposed by this study, requires that the strategy and its application to the context of university management are originated from a set of favorable or unfavorable variables, that will form along a certain temporary lapse by the culture of the organization itself, its environment, its capacity to implement changes, its technologic apparatus, its economic stability, its internal policy and, above all, the professional capacity of its managers. In this way, the university must reinvent itself, shaking its old beliefs to give responses to address the future. But then, what is university today, and what do we want it to become?

\subsection{CLOUD UNIVERSITY: A THEORETICAL ESSAY}

As seen in the previous sections, the university is understood from two different, and many times conflicting, standpoints, and because of that both sides sometimes stand to inflate their positions. As education is seen just as a commodity, the university is deprived of all its autonomy and of its essential educational, research and social functions. On the other hand, when it is seen as a public 
institution, sometimes, it becomes an island, dislodged from reality and considered inefficient and inept, because it does not respond to the needs of the market, of the society and of the organizations.

So, we ask: Which is the university for the new century? The answer is a challenge, and we do not intend here to be modest and skip the problem, we want to raise the issue to be debated and enriched by academic contributions. We hope someday someone will be brave enough to test our assumption, to prove whether it works.

We will utilize the metaphor of the "University in a Matchbox" as a representation of the strategic management model used nowadays in most of the higher education organizations, and the metaphor of the "Cloud University" to illustrate the theoretical propositions in this article. Well, what is "Cloud University"? What is the difference between "Cloud University" and "University in a Matchbox"?

The university in a matchbox is a segmented grouping of autonomous professionals acting together to qualify people who seek different goals. The cloud university is a less segmented group of autonomous professionals acting together to qualify people who seek different goals.

So, what is the difference between those models? The difference is the organizational form. In the segmented university model, which comes from the great specialization of the $20^{\text {th }}$ Century, and from the answers given to the methods of the Natural Sciences applied to the Humanity Sciences, the university was divided into great areas, centers and, eventually, courses. Afterwards, those courses were even more divided, increasing their specializations to the follow up and resolution of problems concerning a particular object, generally speaking, getting adapted to the Taylorist model of organization.

We believe that the exacerbated segmentation, beyond making the mechanism of knowledge generation of the universities more efficient, at today's level, makes the interface between the different areas even more difficult, losing efficacy and efficiency. The dynamics of the market and the extremely quick changes that occur every day require a very quick response from the university institutions, something that their present management strategy is incapable of conceiving. 
University is not, however, the first institution/organization to face the challenges of contemporary times. The reduction of that segmentation is a management contemporary phenomenon that has already assailed military institutions worldwide, as demonstrated below.

For example, the constitution of the "Joint Helicopter Command (JHC)" in the United Kingdom, where, since 1999, the squadrons of the rotary wings belonging to the British military defense (Royal Air Force, British Army and Royal Navy) have been acting jointly in the mission of "providing and supporting the squads of effective combat rotary wings and other air assault assets, operationally capable of acting under any weather conditions, in order to support British Defense missions and tasks". Its formation is presented, as stated by Hewson (2001/2002) in a singular and pioneer organization.

Traditionally, there is a great rivalry between the military corporations, but today there has been an effort for integrating rather than compartmentalizing. New programs of the fighter aircrafts to serve both the Navy and the Air Force in countries which possess aircraft carriers; the Joint Command Harrier (JHC) for the joint operation of the Harrier aircrafts by Royal Air Force (RAF); and the Fleet Air Army (FAA) also illustrate this context. The Cloud University, as a serious management strategy would be, therefore, a version of what occurs in the Defense Departments ${ }^{1}$ worldwide $^{2}$.

Therefore, what are the propositions to the "university for the new century"? We will present below seven propositions on how to manage our universities, and we will call their integration "the cloud university model".

PICTURE ONE - STRATEGIC PROPOSITIONS FOR THE NEW MANAGEMENT OF UNIVERSITIES (THE CLOUD HYPOTHESIS)

PROPOSITION

Curriculum flexibilization
TRADITIONAL UNIVERSITY

Little flexibilization
CLOUD UNIVERSITY

Courses with highly flexible curricular units, the professional councils should propose the core units for formation

\footnotetext{
${ }^{1}$ We suggest the reader to access the contents of Jane's IHS (http://www.janes.com/) for military matters.

${ }^{2}$ The choice of the military institutions for this comparison is due to their ancestry and traditions (conditions also existing in most of the universities in general), which implicated in difficulties in the transition to the conditions required by the capitalist and free-market means of production. We also considered their pioneering in the use of the strategy, which is demonstrated by the heraldic of the term that is also linked to the military environment. In this way, we believe that the analogy expresses best the challenges the universities must face in this century.
} 


\begin{tabular}{|c|c|c|}
\hline Professionalization & $\begin{array}{l}\text { Pre-established units, the student } \\
\text { cannot direct their options according } \\
\text { to needs }\end{array}$ & $\begin{array}{l}\text { Student and university will direct the } \\
\text { courses according to aptitudes }\end{array}$ \\
\hline Interdisciplinary dialogue & Minimum interdisciplinary dialogue & Broad interdisciplinary dialogue \\
\hline Areas of Excellence & $\begin{array}{l}\text { The university must be excellent in all } \\
\text { areas }\end{array}$ & $\begin{array}{l}\text { If not possible to reach excellence } \\
\text { levels in all areas, the university must } \\
\text { identify the areas of excellence and } \\
\text { direct their actions from them }\end{array}$ \\
\hline Basic units & Courses as basic units & Areas as basic units \\
\hline Universality & $\begin{array}{l}\text { University that aims at comprising all } \\
\text { areas and courses }\end{array}$ & $\begin{array}{l}\text { The non-profitable courses do not } \\
\text { extinguish, they will have their } \\
\text { curricula adapted to areas of } \\
\text { excellence of the institution. }\end{array}$ \\
\hline $\begin{array}{l}\text { Courses aimed at the area of } \\
\text { excellence }\end{array}$ & Non-autonomous courses & $\begin{array}{l}\text { The university, as an autonomous } \\
\text { institution must advise their courses to } \\
\text { concentrate in aspects where they will } \\
\text { reach excellence. }\end{array}$ \\
\hline
\end{tabular}

The authors (2013)

As seen in Table 1, the cloud assumption is a tool to help managers understand and verify the good social role the university plays, either towards the market or towards a social activity. We will explain briefly our propositions as follows.

Our three first propositions concern the curriculum. Curriculum flexibility (1); students' and universities' vocationing (2); and the interdisciplinary dialogue (3): today the student ingresses in pre-established curricular units. However, in all areas of the sciences there are subareas of specialization and, quite often, due to the strong attachment to a particular theoretical school, the Academic Board and University Committees eventually direct the pupils through a pre-established way (curricula), which sometimes does not meet the student's future interests.

As an example, in the International Relations area (I.R.) there is a wide range of curricular dynamics. The course of the University of the South of Santa Catarina (UNISUL), where we, authors, teach and research, is totally committed with the Business area. On the other hand, our closest neighbors, the courses of the Federal University of Santa Catarina (UFSC) and University of Itajai Valley (UNIVALI) 
are, respectively, committed with Economics and External Politics. This also occurs with other courses and institutions ${ }^{3}$.

We believe that even in cases where the curricula are according to the areas of excellence of their institutions, the students should be able to adapt their curriculum to their needs. A student who has decided to focus on Political Science could need some more disciplines on economics or management area, for example, which he could easily find in other courses of the same institution or other institutions. However, due to the fixed curricula, he/she may have to attend other disciplines that are not especially interesting for him/her.

Thus, we defend a global standardization of a minimum set of disciplines considered for the qualification in a particular area, established by the controlling offices, with the contribution of all the stakeholders - as an example, the universities together with the professional councils and the student unions. Such nucleus should be essentially basic, so that the student will be able to direct his/her actions in the subsequent stages, accessing within the university the disciplines needed for his/her individual formation.

According to the cognitive science, human beings can understand better the world around him/her through image visualization. Therefore, we dedicated a good part of our efforts here in the task of constructing the diagram below that will illustrate all that is explained about the conception of the hypothesis of the cloud university. Observe the choices of four of the I.R. students in the diagram.

DIAGRAM ONE: ACADEMIC TRAJECTORIES IN THE “CLOUD UNIVERSITY”

\footnotetext{
${ }^{3}$ For further information on the multiplicity of curricular emphases in I.R. courses in Brazil, see: Cesa, G. (2012, April). Relações Internacionais no ENADE: Desafios e perspectivas. In $9^{\mathbf{a}}$ ANPED SUL.
} 


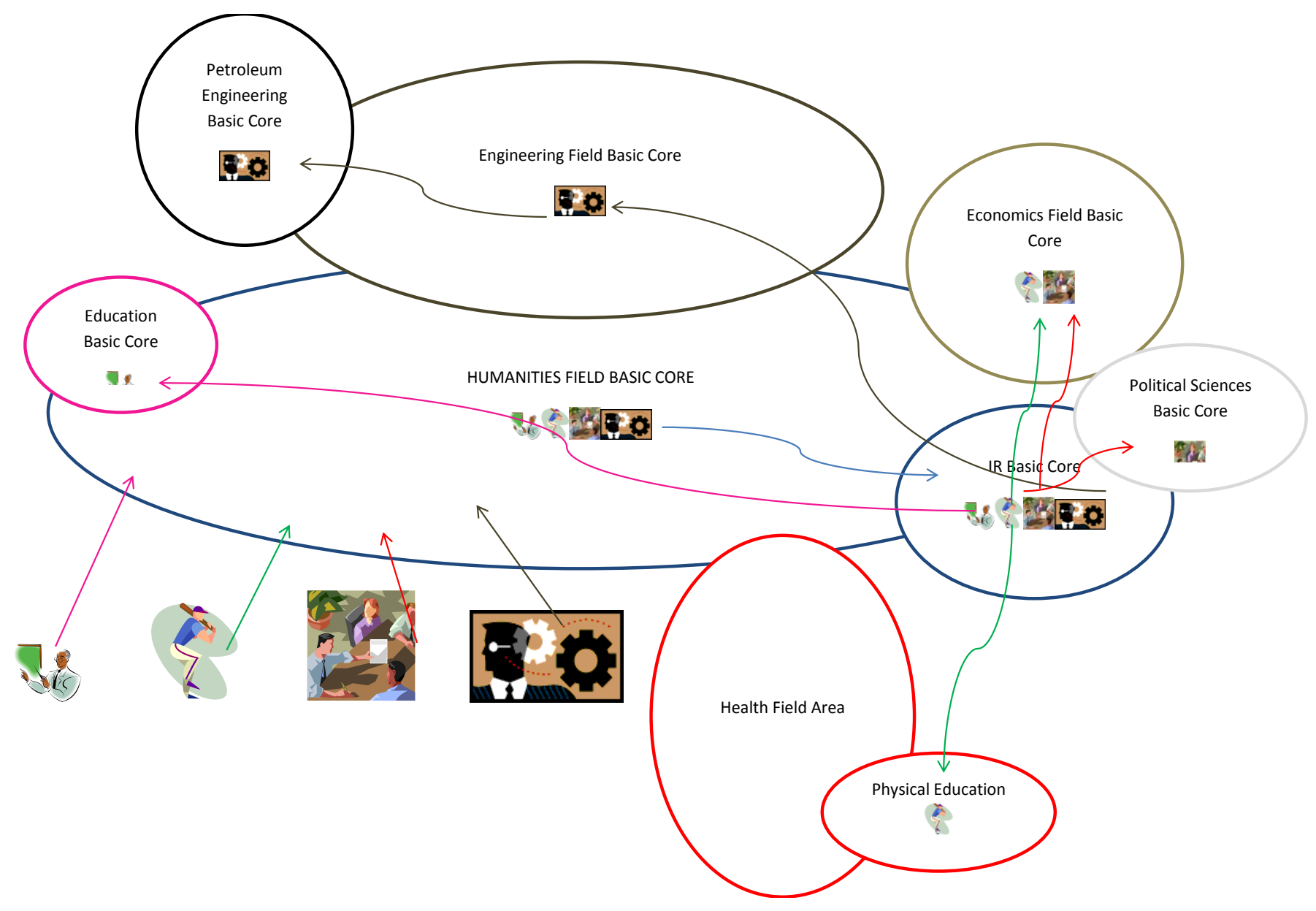

The authors (2013)

Four students enroll in the same course. However, during their formation, the first student (1) learns about the research dynamics of the university and decides he/she wants to follow academic career. With this in mind, he/she can crisscross the I.R. disciplines - which are directed to business- with other disciplines of the educational area that are required for his/her professional future as a scholar. Those disciplines are available in an open university, but he/she cannot access them in a traditional university. So, he/she has to spend his/her economic resources and time to attend disciplines that are not relevant to him/her.

The second student (2) has always liked sports, and has just begun to work in the local soccer team. Many negotiations are in international level when hiring athletes. To evaluate properly the employment and the hiring conditions, the student (2) must be aware of the physiologic factors that influence the athletes; he/she must be prepared to evaluate the performance of the candidates. This approach can be found in the Physical Education course. He can also apply for the disciplines of 
Economy to understand the economic factors involving the negotiation and the management of the international risks when negotiating international athletes.

The third student (3) gets in contact with the students' political activities and decides that Politics would be his/her future professional occupation. So, in addition to the several relevant disciplines in the I.R. course, he/she must take other disciplines in Economy and Political Sciences to deepen his/her specific knowledge.

Yet the fourth student (4) is hired for an internship by a big engineering holding in the very beginning of his/her course. His/her function is to assist the gas and petrol department in international issues. As the student will need basic gas and petrol engineering knowledge to understand the characteristics of this market, he/she could access the specific knowledge in other areas of his/her institution.

Multiculturality and a holistic and international view would remain essential in their formation area, and they would have all the common basic and mandatory disciplines offered by the International Relations Basic Module. This proposal meets the three first assumptions of the Cloud University: curricula flexibility and vocationing to the professional area together with an open interdisciplinary dialogue.

The following four premises of the Cloud University are found in the institution/organization: Areas of excellence (4); Basic Units (5); Universality (6); Courses Directed to the Areas of Excellence (7). In relation to the area of excellence, unlike the traditional universities that understood that university is universal and must be present and offer the highest standards in all areas, we accept here that the market dynamics makes it extremely difficult for all the institutions to reach an excellent level in absolutely all the areas. We understand that there will always be an outstanding area. Thus, the Cloud University suggests performance evaluation tests, as, for example, the MCDA$\mathrm{C}^{4}$, to identify the areas of excellence so that the university can focus and act directly into them.

Our fifth suggestion is that the courses should not be the basic unit, but a great area for the students' admission. Within a great area, for instance, if Administration is more highlighted as a career in the Humanities Department, it may begin to direct the other courses. That is, on the one

\footnotetext{
${ }^{4}$ For further information on methodology MCDA-C we recommend the following article and authors: ENSSLIN, L., DUTRA, A., \& ENSSLIN, S. R. (2000). MCDA: a constructivist approach to the management of human resources at a governmental agency. International Transactions in Operational Research, 7(1), 79-100.
} 
hand, the student would have the opportunity to choose his/her own direction; on the other, the institution would offer him/her the opportunity to access its best in terms of knowledge. For that, all the Humanity courses of that university would emphasize the administrative aspects, and, thus, it is expected that (it must be tested, as all hypothesis) they can ascend qualitatively in a more efficient way than in similar courses in traditional universities.

All of the above go against the "universality of the university". This does not mean, on the other hand, that the university as a cloud assumes that the imperatives of a good economic management suggest the end of non-profitable courses. The concept of profitability, together with the university's social viewpoint, prevents non-profitable courses to be excluded, since they play a role in the construction of the science. Although they may not give any financial compensation, those courses return in theories that can be the basis for very important discoveries in the future.

To maintain those courses, the university as a cloud adapts its curricula to the areas of excellence of the institution, which is the core of the proposition (7), with fewer professors, who, in turn, will be more linked to the other collegiates. That body would be responsible for the application of a basic module of disciplines. In this way it is expected that the course succeeds, and that it gains enough reputation in order to apply for financial support to grow and gain autonomy.

We believe here that the investors play a fundamental role that not even an autonomous university can ignore. The investors (the State, students, private entities, and sectors of the society in general) are interested in the return of their funds to guarantee the survival of the institutions as a whole. To comply with those interests should guarantee the necessary resources to maintain the most unprofitable areas of the university, always bearing in mind that such areas must work hard to overcome the deficit and eventually give some social return.

The publicity of any of the social returns to the society must be preponderant. Marketing is the soul of business! The social development rates, along with the growing number of vacancies, can show the civil and academic societies that the money invested, for example, in an unprofitable pedagogy course, was not wasted. In this way, the course may get more visibility and attention.

Now, let us focus again on our four I.R. students. They are now enrolled in a traditional university. In the diagram below we use the example of the flowchart of the International Relations course of the University of Southern Catarina (UNISUL) to demonstrate how these individuals, whose hypothetical 
trajectories were presented in diagram one, can pursuit their careers in a university constituted by the traditional model that we here call "university in a matchbox".

\section{DIAGRAM 2: Academic Trajectories in the "University in a Matchbox"}

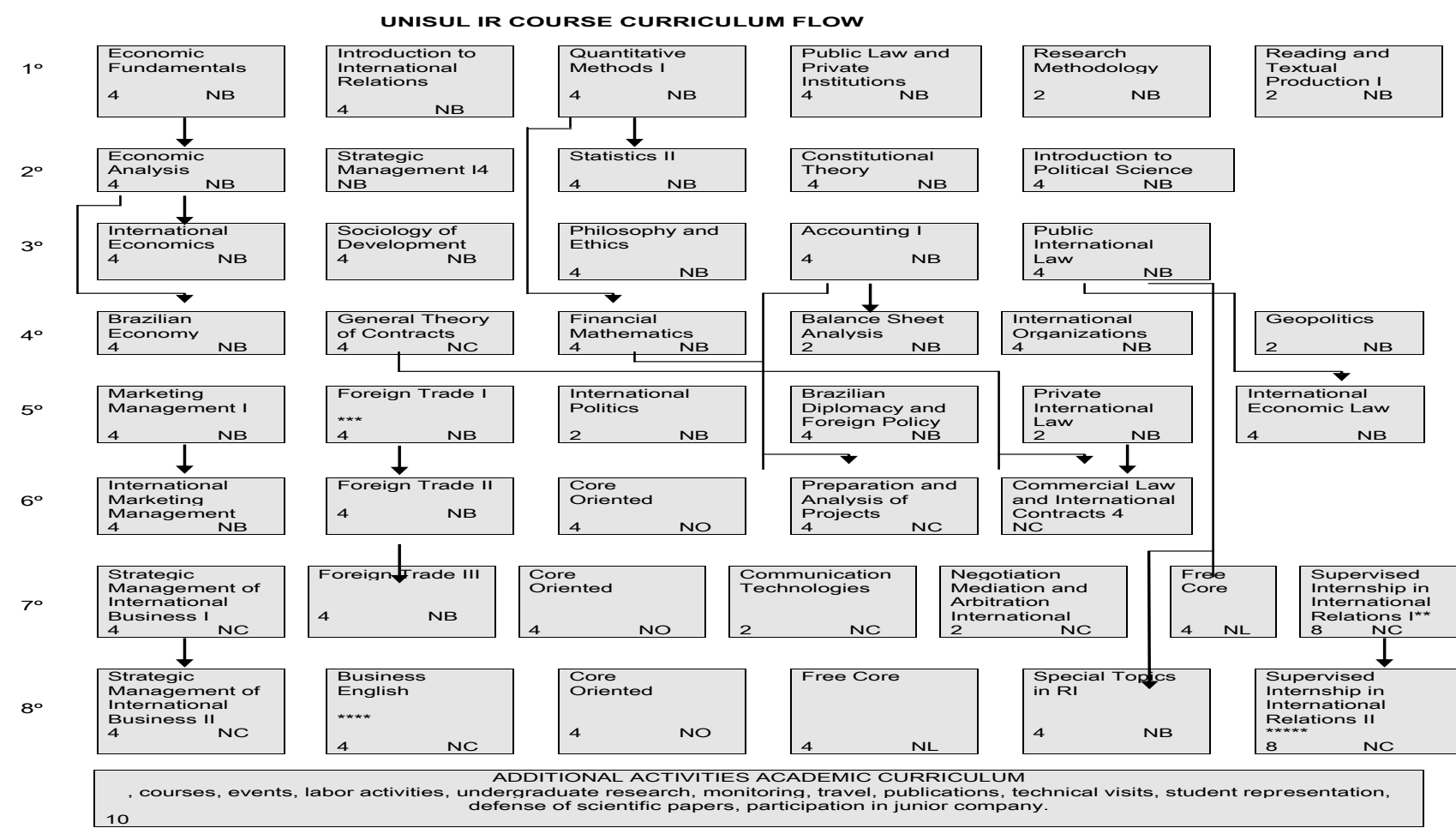

Source: UNISUL (2013)

The same individuals will have to attend disciplines in their areas; they cannot seek interdisciplinary contents to count as academic credits in their course. Thus, we can infer that a substantial amount of the students from traditional institutions eventually drop out from one course and take up another, due to their changes in trajectory as they are inserted in society or in the market. If such assumption is confirmed, it means an enormous amount of resources wasted by the institution, the society and the individuals. The proportion of such losses is determined by the supporting model of education. However, such waste of time and money must be faced, no matter the nature of the educational systems in force in each State.

\subsection{FINAL CONSIDERATIONS}

This was a qualitative and exploratory (metaphoric) theoretical essay, based on a deductivehypothetical approach. We worked on the elaboration of the "cloud" and "matchbox" metaphors to 
translate the thoughts of the authors in relation to the "must be" and the "is" in university management.

The problem of the research was to look for a strategy that may contribute for the good performance of the university, uniting social responsibility and economic imperatives. The investigation is limited by the proposition of a new hypothesis to solve the problem exposed, called the "cloud university management model".

The results reflected the authors' position in relation to the structural elaboration of a new management model called "Cloud University" that must be explored as a new possibility of strategic management in universities. The model focuses seven essential competences to be developed by the institution to generate favorable performance, in the broader sense of the word, comprising the social and economic spheres, that is: the flexibilization of the curricula, vocationing, interdisciplinary dialogue, areas of excellence, basic units, universality and courses aimed at the areas of excellence. We compare the possible trajectory of four different-profile students that enroll in the "Cloud University" with a flowchart of a course from a traditional institution, the "University in a Matchbox".

The biggest limitation was the impossibility to execute laboratory tests to measure the potential effects of the "cloud management" at the institution and the subsequent empirical test of the management model proposed being applied to the real context of a university. Finally we assume that in the traditional institutions a substantial part of the students drop out and begin another course due to the changes of trajectory in society and in the market.

Therefore, as a suggestion for further studies, we propose that we should look for an institution that is interested in understanding the possibilities of profits with this hypothetical management model, and the execution of laboratory tests and simulations to prove the empirical viability to employ this model to that specific context, considering the occasional limitations imposed by the stakeholders. Another suggestion is to test the assumption that universities, society, the State and the market lose resources due to the students' dropping out and taking up another course along their academic trajectories. 


\subsection{REFERENCES}

AMARAL, Juliano Franco e Silva. Estratégias de gestão empresarial. In: Revista PRETEXTO. Belo Horizonte, v. 6, ano I, p. 59-74, jul. 2005.

ANSOFF, H. I.; MCDONNELL, E. J. Implantando a administração estratégica. 2. ed. São Paulo: Atlas, 1993.

APPOLINÁRIO, Fabio. Metodologia da ciência: filosofia e prática da pesquisa. São Paulo: Cengage Learning, 2009. p.59-63.

BALDRIDGE, J. V. (1982). Shared governance: A fable about the lost magic kingdom. Academe, 68(1), 12-15.

BANCO MUNDIAL. El financiamiento de la educación en los países en desarrollo: opciones de política. Washington, DC, 1986.

- (1994) La Enseñanza Superior: las lecciones derivadas de la experiencia (El Desarrollo en la práctica). Washington, D.C.: BIRD/Banco Mundial.

BANCO MUNDIAL/Johnstone D.B. (coll. Alka Arora and William Experton). (1998) The Financing and Management of Higher Education: A Status Report on Worldwide Reforms.

BARNEY, Jay. Firm Resources and Sustained Competitive Advantage. Journal of Management. 1991, Vol. 17, No.1, 99-120

CHAUÍ, M. (2003). A universidade pública sob nova perspectiva. Revista Brasileira de Educação, 24, 515.

COHEN, M. D., \& MARCH, J. G. (1986). Leadership and ambiguity: The American college president. Harvard Business Press.

DE ANDRADE, A. R. (2002). A universidade como organização complexa. Revista de Negócios (prefixo doi 10.7867), 7(3).

EISENHARDT, K. M., \& MARTIN, J. A. (2000). Dynamic capabilities: what are they? Strategic Management Journal, 21(10-11), 1105-1121.

FERREIRA, Aurélio Buarque de Holanda. Miniaurélio: o dicionário da língua portuguesa. 6. ed. Curitiba: Positivo, 2006.

FURRER, O., THOMAS, H., \& GOUSSEVSKAIA, A. (2008). The structure and evolution of the strategic management field: A content analysis of 26 years of strategic management research. International Journal of Management Reviews, 10(1), 1-23.

HEERDT, Mauri Luiz; LEONEL, Vilson. Metodologia científica e da pesquisa: livro didático. Palhoça: ed.Unisulvirtual, 2007.

HENDERSON, B. D. As origens da estratégia. 2. ed. Rio de Janeiro: Campus, 1998. 
HEWSON, Robert. JHC Eficiência Máxima: O comando conjunto de helicópteros das Forças Armadas Britânicas. Revista Força Aérea: A Revista Brasileira de Aviação Militar, Rio de Janeiro, n. 25, p.50-57, Dez./Jan./Fev.2001/2002.

ITO, N. C., \& GIMENEZ, F. A. P. (2011). Uma conversa entre Porter e VBR: Framework do valor da transação da vantagem competitiva. Revista Organizações em Contexto-online, 7(14), 29-56.

MEIRELLES, A. de M. A formação de estratégia no sistema bancário brasileiro: modelo teórico e evidências empíricas. Tese (Doutorado em Administração). Belo Horizonte. UFMG/CEPEAD, 2003.

MEYER JR, V. (2005). Planejamento universitário: ato racional, político ou simbólico: um estudo de universidades brasileiras. Revista Alcance, 12(3), 373-389.

MILLETT, J. D. (1962). The academic community: An essay on organization. New York: McGraw-Hill.

MINTZBERG, H.; AHLSTRAND, B. \& LAMPEL, J. Safári de estratégia: um roteiro pela selva do planejamento estratégico. Porto Alegre: Bookman, 2000.

MINTZBERG, H.; LAMPEL, J.; QUINN, J. B. \& GHOSHAL, S. O processo da estratégia: conceitos, contextos e casos selecionados. 4.ed. Porto Alegre: Bookman, 2006.

MINTZBERG, H.; QUINN, J. B. O processo da estratégia. Porto Alegre: Bookman, 2001.

MORGAN, Gareth. Paradigms, Methaphors, and puzzle solving in organization theory. Administrative Science Quaterly, V.25, n.4, p.605-622, 1980.

PENROSE, E. A teoria do crescimento da firma. Campinas-SP: Editora da Unicamp, 2006.

PETTIGREW, A. M. Strategy formulation as a political process. International Studies of Management \& Organization, v. 7, n. 2, p. 78-87, summer, 1977.

PORTER, M. E. Competição: estratégias competitivas essenciais. Rio de Janeiro: Campus, 1999.

REALI, G., \& ANTISERI, D. (1991). História da filosofia: do romantismo até nossos dias. São Paulo: Paulus.p.1025-1026.

RIZZATTI, G., \& DOBES, C. (2004). A complexidade do processo decisório em universidades. Cenários da gestão universitária na contemporaneidade. Florianópolis: Insular, 185-192.

SELLTIZ (1965) apud MARCONI, Marina de Andrade; LAKATOS, Eva Maria. Técnicas de pesquisa: planejamento e execução de pesquisas, amostragens e técnicas de pesquisas, elaboração, análise e interpretação de dados. 4.ed. São Paulo: Atlas, 1999. p. 21-23.

SGUISSARDI, V. (2005). Universidade pública estatal: entre o público e o privado/mercantil. Educação \& Sociedade, 26(90), 191-222.

(2008). Regulação estatal versus cultura de avaliação institucional. Avaliação: Revista da Avaliação da Educação Superior, Campinas, 857-862.

SOBRINHO, J. D. (2004). Avaliação ética e política em função da educação como direito público ou como mercadoria. Educação e Sociedade, 25(88), 1-13. 
. (2008 a). Avaliação educativa: produção de sentidos com valor de formação. Avaliação: Revista da Avaliação da Educação Superior, 13(1), 193-207.

- (2008 b). Quality, evaluation: from SINAES to indexes. Avaliação: Revista da Avaliação da Educação Superior (Campinas), 13(3), 817-825.

TRIVIÑOS, Augusto N. Introdução à pesquisa em ciências sociais: a pesquisa qualitativa em educação. São Paulo: Atlas, 2011.

WEICK, K. E. (1976). Educational organizations as loosely coupled systems. Administrative Science Quarterly, 1-19. 